Cornell Law Library

Scholarship@Cornell Law: A Digital Repository

Cornell Law Faculty Working Papers

Faculty Scholarship

$4-25-2012$

\title{
Changing Social Security to Achieve Long-Term Solvency and Make Other Improvements: Background Factors, Issues, Options
}

Peter W. Martin

Cornell Law School, peter.martin@cornell.edu

Follow this and additional works at: http://scholarship.law.cornell.edu/clsops_papers

Part of the Elder Law Commons, Social Welfare Law Commons, and the Women Commons

\section{Recommended Citation}

Martin, Peter W., "Changing Social Security to Achieve Long-Term Solvency and Make Other Improvements: Background Factors, Issues, Options" (2012). Cornell Law Faculty Working Papers. Paper 98.

http://scholarship.law.cornell.edu/clsops_papers/98 


\title{
Changing Social Security to Achieve Long-Term Solvency and Make Other Improvements - Background Factors, Issues, Options*
}

\author{
Peter W. Martin**
}

\section{Introduction}

For years those responsible for Social Security and policy analysts have acknowledged that the present statutory framework for determining and financing program benefits is unsustainable. The underlying factors are not a matter of dispute. An apparently permanent shift in the ratio of individuals of working age paying into the system to those receiving benefits from it constitutes the principal cause. Because of a demographic bulge (the "baby boom") this change is occurring fairly abruptly. A drop from roughly three covered workers per beneficiary to two per beneficiary began in 2010 and will be complete around 2020. The nation's declining birth rate has reduced the relative number of workers paying in, even as increased longevity is exanding the population of beneficiaries. Retirees are living significantly longer than in 1983 when Congress last adjusted the program's key parameters. In sum, as is true of other economically developed countries, the U.S. population is aging. That carries direct funding challenges for Social Security, Medicare, and most other mechanisms, public and private, designed to support those in retirement.

\section{Figure $1^{1}$}

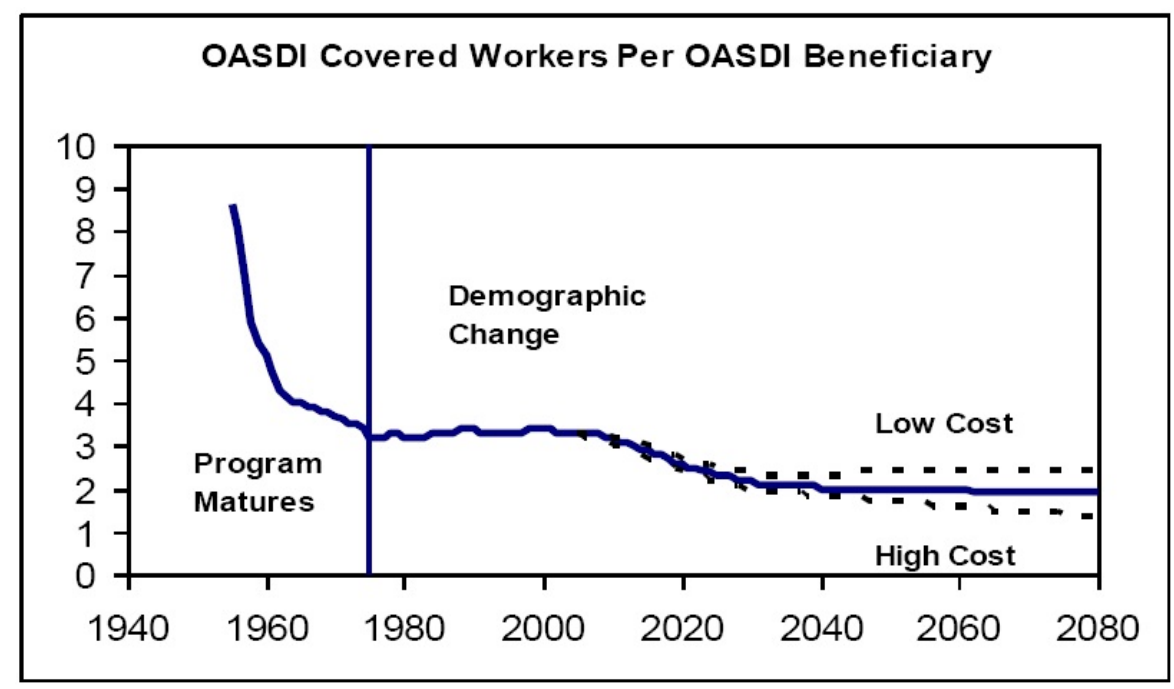

Other demographic and economic conditions have, over time, diverged significantly from assumptions that informed details of Social Security's architecture. Some of these changes have also increased program costs or reduced revenues, adding to the long-term sustainability problem. For example, earnings inequality has increased dramatically. As a result, an ever larger fraction of U.S. earnings exceed the income 
range upon which the Social Security payroll tax is imposed. Other developments with less clear fiscal impact have nonetheless produced results that seem quite at odds with those originally intended. Some raise serious issues of fairness or adequacy. As explored in greater detail below, Social Security's spouse benefits remain an important feature for women, notwithstanding the steady climb in female labor force participation. Yet a structure that channels non-contributory benefits to spouses, and more particularly spouses in marriages that exist in old age, whether or not of long duration, and divorced spouses whose marriages spanned at least ten years, seems less and less congruent with U.S. patterns of work and family composition. An even more clearly obsolete element is Social Security's special minimum benefit. Designed to provide minimally adequate amounts to workers retiring after a lifetime of low wages, it was indexed to prices. Since the standard benefit formula rises with average earnings, this alternative benefit formula has been rendered almost entirely valueless. ${ }^{2}$ Yet the standard formula, when applied to the earnings history of a steadily employed, low wage worker, produces benefits well below the poverty line. ${ }^{3}$

Long ago, the discussion among experts about Social Security’s fiscal problem, amplified by political debate over its dimensions and possible solutions, began to impinge on public consciousness, sapping the confidence of those paying into the system. Periodic Gallup surveys show that in recent years a majority of current workers have come to believe that Social Security benefits will no longer be there when their time to retire arrives, with this concern being particularly acute among individuals18 to 34 years old.

\section{Figure $2^{4}$}

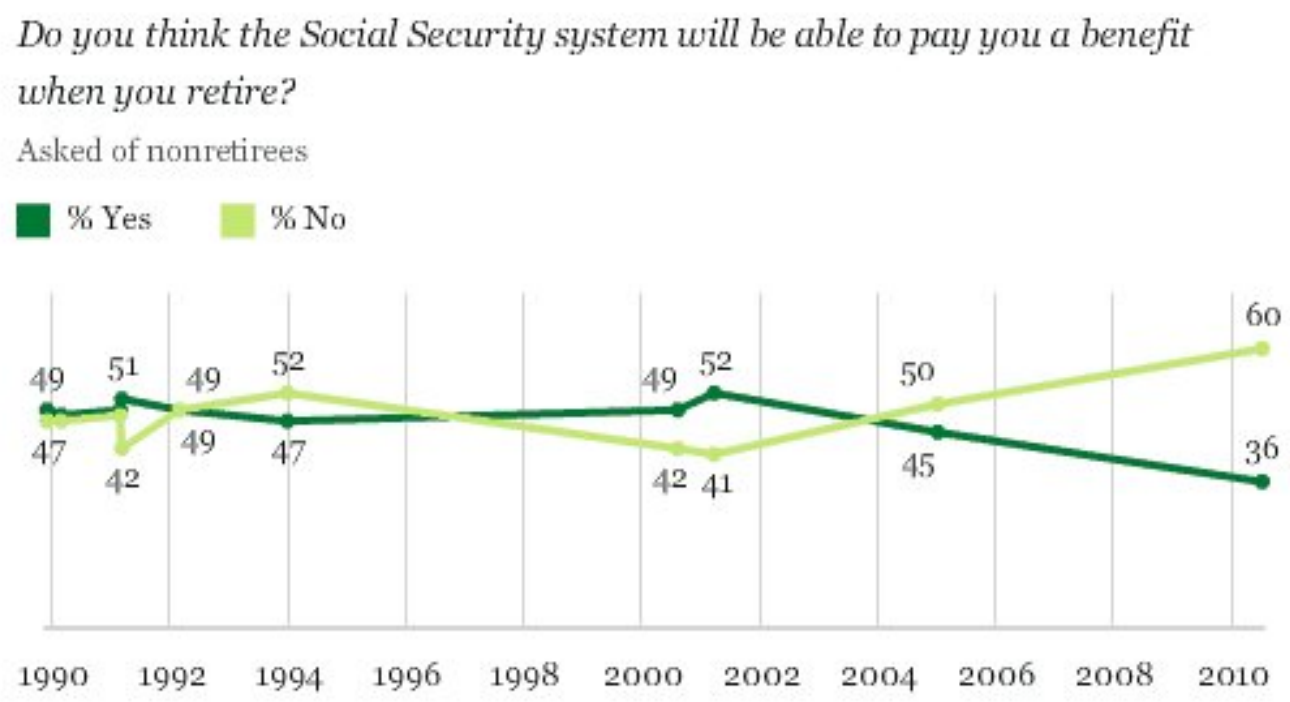

\section{GALLUP}

Nonetheless, despite the work of Presidential commissions, ${ }^{5}$ countless Congressional hearings, proposals for reform advanced by individuals and groups across the political spectrum, changes to Social Security that would restore its fiscal balance into the foreseeable future have repeatedly been deferred or deflected by the nation's lawmakers. This postponement of solution is itself a matter of concern. For over a 
decade, the Social Security Advisory Board ${ }^{6}$ has urged prompt action to restore Social Security's long-term solvency. As its 2010 report "Social Security: Why Action Should Be Taken Soon” explains, delay results in ever more constricted options, continued erosion of public confidence in the program, increased economic instability, and diminished opportunity for spreading the impact of necessary changes over time and across age groups. ${ }^{7}$

Failure to act has also eroded Social Security's capacity to weather recession. The Social Security Trustees Report submitted to Congress in April 2007 painted the system's short-term future as secure. ${ }^{8}$ Unforeseen economic events rapidly changed that picture. A massive decline in employment cut into the program's principal revenue source, the earmarked taxes paid on earnings by employers and employees. Declining interest rates reduced a second important source of funds, the interest paid on the U.S. Treasury bonds held by the two Social Security trust funds. And benefit applications increased. Finding themselves without employment, older individuals who had not planned to retire so soon applied for Social Security. Jobless individuals who had previously managed to work despite severe medical problems applied for Disability Insurance, as just they had in earlier periods of economic contraction.

Figure 3: The Effect of Recessions on Disability Insurance ${ }^{9}$

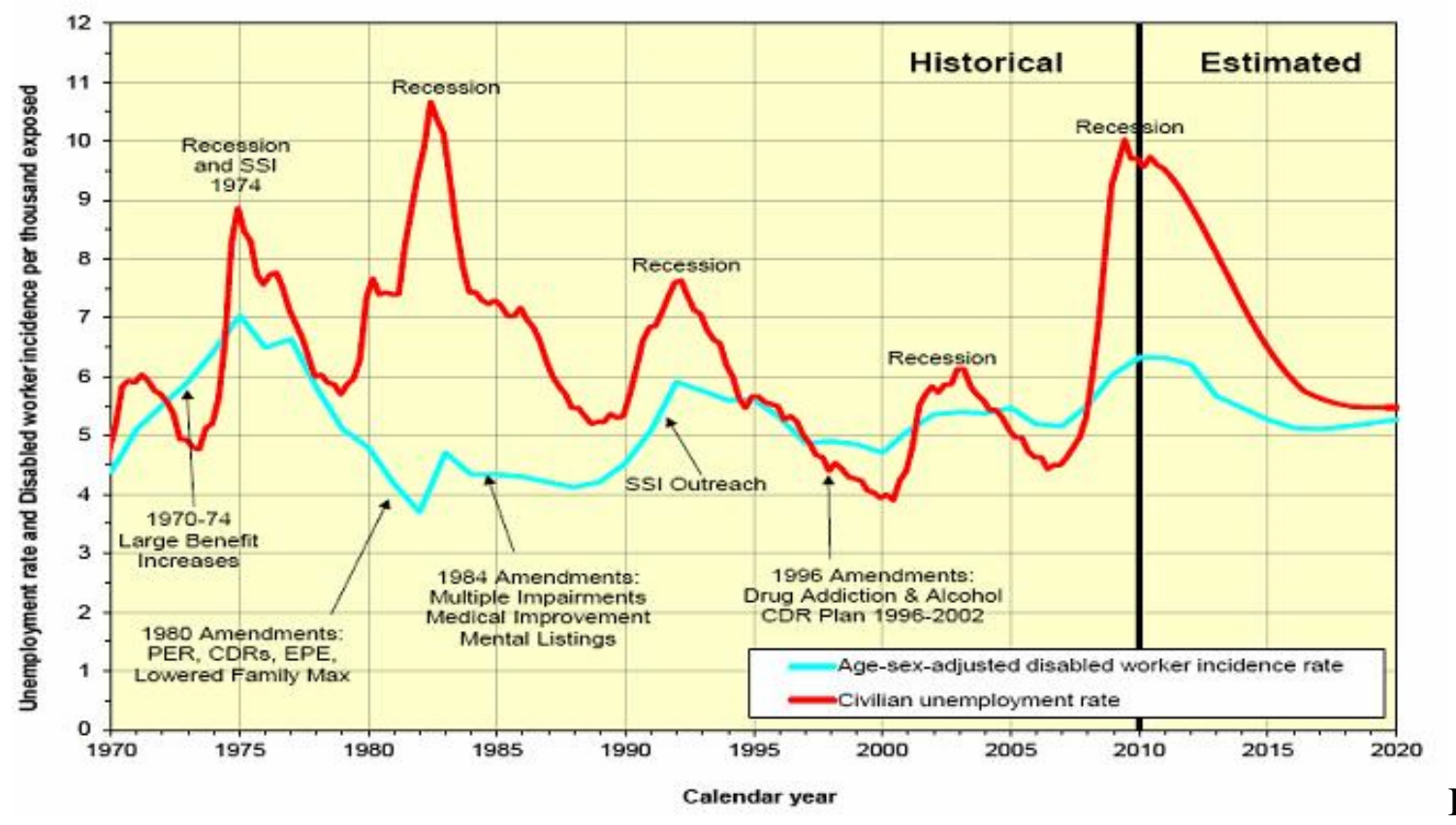

By 2011 the trustees were forced to report the likelihood that the assets of the Disability Insurance (DI) Trust Fund would be exhausted by 2018. ${ }^{10}$ Their 2012 report brought that date forward to 2016. ${ }^{11}$ The 2012 report also estimated that the Old Age and Survivors Insurance (OASI) Trust Fund, while able during the short term to cover both that program's costs and the shortfall in DI, would in 2016 have assets totalling one-third less than the trustees had projected before the recession, a reduction of over $\$ 1.5$ trillion. ${ }^{12}$ Total Social Security benefits paid out in 2010 were $\$ 17.3$ billion more than had been forecast in 2007; program revenues were $\$ 153.9$ billion less. ${ }^{13}$ It should, perhaps, be added that none of that revenue decline was a consequence of the two percent payroll tax 
holiday enacted as a stimulus measure for 2011 and subsequently extended through 2012. Since the effectuating legislation authorized compensating transfers from general revenues and made no change in the earnings levels on which future benefits would be calculated these temporary tax reductions had no direct fiscal impact on Social Security. ${ }^{14}$

This paper aims to assist analysis of and reflection on the range of options for ensuring Social Security's future while avoiding the addition of yet another solvency proposal to the already ample supply. It begins with several background observations. These are followed by a discussion of personal (or private) accounts to which former President George W. Bush gave salience and which continue to be included among the talking points of politicians hostile to Social Security's historic structure. Next the paper reviews the more likely program changes that would (unlike personal accounts) directly address Social Security's long-term “deficit.” That section is followed by one sketching possible revisions in the program's benefit structure designed to achieve ends other than reducing Social Security expenditures. The paper concludes with some observations on the role that framing has played in past debates over Social Security's future. Finally, there is an appendix explaining the central terms and components of the current program. It is provided for readers who might otherwise be unclear about the meaning or implications of changing Social Security's “Primary Insurance Amount” formula or its "Full Retirement Age."

\section{Important Background Points}

\section{A. Achieving sustainability}

For years the standard actuarial analysis employed in Social Security's annual trustees' reports has revealed a large long-term deficit. Over the past decade and a half these successive seventy-five year projections placed the size of that deficit at around $2 \%$ of taxable earnings. ${ }^{15}$ The two most recent reports have increased the estimate to $2.22 \%$ in $2011,2.67 \%$ in $2012 .{ }^{16}$ In other words, achieving balance or solvency measured this way would, roughly speaking, require raising annual revenue over the figure generated under current law by an amount equivalent to adding the estimated percentage to the payroll tax rate immediately and permanently or cutting program costs by that amount or some combination of the two, over the next seventy-five years. An asserted failure of vision in the last iteration of Social Security reform, which took place roughly three decades ago, is that it did not escape this definition of solvency. The "sustainability" critique points toward an even more distant time horizon or at least analysis of the revenue-cost dynamic toward the end of the conventional seventy-five year period. Program revenue and benefits can be in balance when viewed against a fixed number of years, so the argument goes, but, if at the end of that period costs are climbing and revenues shrinking, identical projections done a year or two later will show a deficit. Diamond and Orszag (see I.F below) refer to this as the "terminal-year problem.",17 Enacting a Social Security tax rate increase of $2.67 \%$ (split between employees and employers) would achieve actuarial balance, as traditionally measured, but according to the trustees' 2012 report it would not produce sustainability for their projections reveal "the program's financial condition ... worsening" at the end of the seventy-five year period. ${ }^{18}$ 
Social Security is close to unique among government programs in having built into its legislation such a mechanism for regular exposure and review of projected future expenditures and consequent revenue requirements. Furthermore, its dedicated funding base brings a rare discipline to that analysis. As noted below, Medicare poses more serious long-term fiscal challenges, but the two parts of Medicare that threaten most explosive growth (Parts $\mathrm{B}$ and $\mathrm{D}$, the latter being the drug benefit program that took effect in January of 2006) are, according to that program's trustees report for 2012, adequately funded. How can that be said? Medicare Parts B and D (unlike Medicare Part A and Social Security) are funded by a draw on general revenues and premiums paid by the population it covers. Those parts of Medicare can be said to be in fiscal balance because the governing legislation allows the trustees to assume that transfers from general revenues and premiums will continue to increase automatically, year by year, covering that year's costs, no matter how high they climb. ${ }^{19}$ Is Medicare in fiscal balance? Technically, yes; realistically and sustainably, no. For seven years in a row the size of Medicare's reliance on general revenues has forced the trustees to issue a statutory "Medicare funding warning.",20

\section{B. The importance of acting sooner rather than later}

Social Security is less than eighty years old. What grounds are there for imagining that today's projections of how the program's present framework will function over the next seventy-five years will be any more accurate than those underlying the original legislation or more recent revisions? Annual trustees' reports not only caution about the uncertainties underlying their actuarial figures, but routinely represent a range of possible futures by offering not one but three long-term projections. ${ }^{21}$ While the one labeled "intermediate" commands greatest attention, the most recent report also contains a "lowcost" or optimistic projection which shows the program as very close to actuarial balance, as well as a truly bleak "high-cost” one. ${ }^{22}$ A 2004 Congressional Budget Office projection of Social Security expenditures and revenues ${ }^{23}$ estimated a much smaller long-term deficit than the program trustees were, at the time, projecting, further illustrating the degree of speculation involved in predicting the effects of economic and demographic changes across three-quarters of a century.

Any number of events or forces, ranging from changes in immigration policy to economic collapse, wars or pandemics, could change Social Security's future in defiance of today's best estimates. Social Security has been deeply affected by economic and social changes that were invisible to forecasters in 1935, 1950, and even $1983 .{ }^{24}$ Surely, the most carefully crafted contemporary reforms will similarly confront unforeseen challenges. Does this recommend a "wait and see" approach? The short answer is "no." It is one thing for Congress to attempt to legislate responsibly for Social Security's future, with realistic acknowledgment that future developments will invariably require future adjustments, quite another to fail to legislate even though the best forecasts indicate a large future problem. On the other hand, because of the certainty of unforeseen challenges it is important that Social Security reform be made within a framework that is, while stable (not requiring constant legislative adjustment), not so rigid as to make future revision unnecessarily arbitrary or politically difficult.

Why not wait to act until Social Security's fiscal shortfall is closer at hand so that its 
dimensions will, presumably, be more clearly visible? As the Comptroller General explained to a Committee of Congress over a decade ago, two powerful reasons not to wait are intergenerational equity and adequate forewarning:

While the crisis is not immediate, it is important to act soon if we are to avoid having to unfairly burden future generations with the program's rising costs and give these individuals time to make necessary adjustments to their retirement planning. $^{25}$

Assuming that solvency requires downward adjustment of the program's benefit formula and higher taxes in some combination, the greater the delay in implementation, the more that burden will be concentrated on younger workers and future cohorts of beneficiaries, with those who fall in both categories taking a double hit. Of course, the intergenerational equity point applies, with equal force, to Medicare, the national debt and U.S. trade imbalance, exploitation of natural resources, and a myriad other issues. It is simply more evident with Social Security because of the way the program is structured.

\section{The relationship between the Social Security reserve and the federal deficit}

The reform package recommended by the Greenspan Commission and enacted by Congress in 1983 avoided the then-quite-imminent Social Security insolvency with a package of tax increases and long-term benefit reductions. As intended, these resulted in a prolonged period of growing surplus or reserves. That growth continues. The 1983 amendments represented a modest shift from "pay as you go" to "advance" funding. Despite proposals to put the Social Security reserves in a "lockbox" or take them off the federal budget the temptation to use them to reduce the apparent size of the federal deficit during the presidencies of Reagan and the Bushes, both senior and junior, and to increase the apparent size of the budget surplus under Clinton proved irresistible. As a consequence, on top of all the debt the Federal Government now owes third parties, it owes the Social Security trust funds over $\$ 2.6$ trillion. $^{26}$ (During $2011 \$ 114.4$ billion, over $14 \%$ of program revenue, came from interest payments on that debt.) ${ }^{27}$ This indebtedness will climb by several hundred million dollars until a year or two or three after 2020 when annual program costs will begin to exceed annual program revenue. ${ }^{28}$ At that point, as the director of the Congressional Budget Office noted in testimony before the Senate Special Committee on Aging in February 2005: "The Social Security system will ... have to redeem the government bonds held in its trust funds. But where will the Treasury find the money to pay for those bonds? Will policymakers cut back other spending in the budget? Will they raise taxes? Or will they borrow more?” Having used the Social Security surplus for decades to support other expenditures the Federal Government will have to begin "repaying" that debt. ${ }^{29}$

One of the asserted advantages of personal accounts invested in the private sector is that advance funding in that form will not present future Congresses with the temptation to make temporary use of the assets for other purposes. That argument rests at bottom on claims about psychology and politics, not law. 


\section{What happens if Congress does nothing?}

The Social Security Act itself appropriates the funds for Social Security benefits. There is no need for the Social Security Administration to secure appropriations year by year to cover benefits. (By contrast, expenditures on the program's administration, although funded from the very same source, the trust funds established by 42 U.S.C. § 401, are subject to annual Congressional approval.) Concerns about imbalance between program revenue and benefit commitments are dealt with primarily through procedural devices designed to alert Congress to any problem. The most important of these is the annual report by the program trustees called for by 41 U.S.C. § 401(c). Section 401 also authorizes inter-fund borrowing as a short-term solution (e.g., the Disability Insurance trust fund can borrow from the Old-Age and Survivors Insurance fund and vice versa). See 42 U.S.C. § 401(l). In addition, the mechanism in 42 U.S.C. § 415 for annual cost-ofliving benefit increases shifts from price to wage indexing, if that yields a lower figure, when the "fund ratio" drops too low. See 42 U.S.C. § 415(i).

There is nothing in the Act that provides for scaling back benefits so that they match revenues. The apparent assumption is that before that became necessary Congress, having been forewarned by the trustees and the chief actuary, would make appropriate adjustments (as it has in the past). Should Congress do nothing and the trust funds experience cash flow embarrassment, the Social Security Administration would have no legal authority to pay benefits beyond the sums flowing in. In the absence of further Congressional direction through amendment to the Act, what the agency would be authorized to do in shaping benefit payments to inadequate revenue is an open question. $^{30}$

\section{E. The comparatively greater challenge posed by Medicare}

The 2012 Trustees Report on Medicare summarized that program’s future as follows:

Total Medicare expenditures were $\$ 549$ billion in 2011. The Board projects that, under current law, expenditures will increase in future years at a somewhat faster pace than either aggregate workers' earnings or the economy overall and that, as a percentage of GDP, they will increase from 3.7 percent in 2011 to 6.7 percent by 2086 (based on the Trustees' intermediate set of assumptions). ${ }^{31}$

It noted further that this projection rested on the unrealistic assumption that the scheduled decrease in physician fees, which Congress had regularly overridden, would finally occur. The estimate also assumed, the report noted, that the cost reduction effects promised by the Affordable Care Act would be realized. The trustees estimated that should those two assumptions prove unsound Medicare costs would increase to 10.4 percent of GDP by $2086 .{ }^{32}$ (That is roughly the percentage of GDP generated by the federal income tax since 1985. $)^{33}$

Comparable projections of Social Security show it rising from its current level (4\% $5 \%$ GDP) to $6 \%$ or so seventy-five years out. ${ }^{34}$

\section{F. One framework for analysis and comparison}

A book by Peter Diamond and Peter Orszag, published in $2004,{ }^{35}$ provides a useful 
framework for approaching these issues: It not only offers thorough analysis of the Social Security financing challenge, but suggests ways of thinking about how best to share the burden of meeting it. That framework leads the authors to propose a three-part plan containing a balance of revenue increases and "benefit adjustments." Two closely related factors that shape the Diamond-Orszag plan are the increased and continually increasing life expectancy for seniors and the substantial inequality within that increase (much greater longevity improvement for high income than for low income workers). The authors do not favor benefit adjustment in the form of further shifts in the "Full Retirement Age" as some others have. Instead they propose automatically reducing the prospective Primary Insurance Amount (PIA) formula for those 59 and younger each year, based on the increase in long-term cost to the program caused by improvement in life expectancy at Full Retirement Age. (Actually, pursuing a pervasive "balance the pain" approach they would divide the impact between Primary Insurance Amount reduction and an upward adjustment of the Social Security tax rate.) The widening gap between life expectancy for higher income and lower income retirees furnishes justification for a proposed reduction in the top band multiplier in the PIA formula from 15\% to $10 \%$. Other features of their plan are shaped in response to increases in earnings inequality. They note: "In 1983 ... 10 percent of earnings were untaxed because they were above the taxable minimum. In 2002, in contrast, the share of earnings above the maximum was about 15 percent." 36 The final factor influencing their plan they term "legacy costs" - the costs that must be borne by present and future workers because earlier cohorts of Social Security recipients were and are paid benefits in excess of those financed by their own contributions. ${ }^{37}$

Two high profile Social Secuity plans put forward as part of more comprehensive deficit reduction proposals floated in 2010 reflected elements of the Diamond-Orzag package together with other components. ${ }^{38}$ Both included:

- An increase in the maximum earnings subject to the Social Security tax with subsequent indexing aimed at taxing $90 \%$ of all earnings

- A gradual reduction of the replacement rate for top earners

- Future benefit formula adjustments to reflect longevity increases, in one case by indexing of the PIA formula, in the other through adjustment of both the age of earliest eligibility and the Full Retirement Age

- Eventual extension of coverage to all newly hired state and local government employees

Additionally, both 2010 proposals sought to improve the information and advice available to inform the retirement planning of future beneficiaries, so as to encourage both more adequate savings and later retirement.

Changes that will solve Social Security's financing challenge necessarily entail measures that can appear politically unpalatable. In comparing options and persuading the public of a particular course of action, having an understandable framework or set of criteria is critical. And the starting premise can be determinative. Some enter this policy debate with the conviction (not necessarily expressed) that the degree of income and intergenerational transfer embedded in this social insurance program is undesirable. 
This leads them to favor solutions producing a much tighter relationship between each worker's pay-in and his or her ultimate lifetime benefits. Others would have the program do even more for low earnings workers. These groups are not likely to favor the same set of changes for achieving program solvency.

\section{G. Social Security and gender}

Notwithstanding its formal gender neutrality, Social Security is a different program for men and women. That means that significant program changes are likely to have a differential impact.

To begin, women live longer than men. That is not only true for those generations currently 65 and older; it appears almost certain to hold true for the generations following directly behind. The longevity gap is projected to narrow somewhat in the years ahead but not disappear.

\section{Figure $4^{39}$}

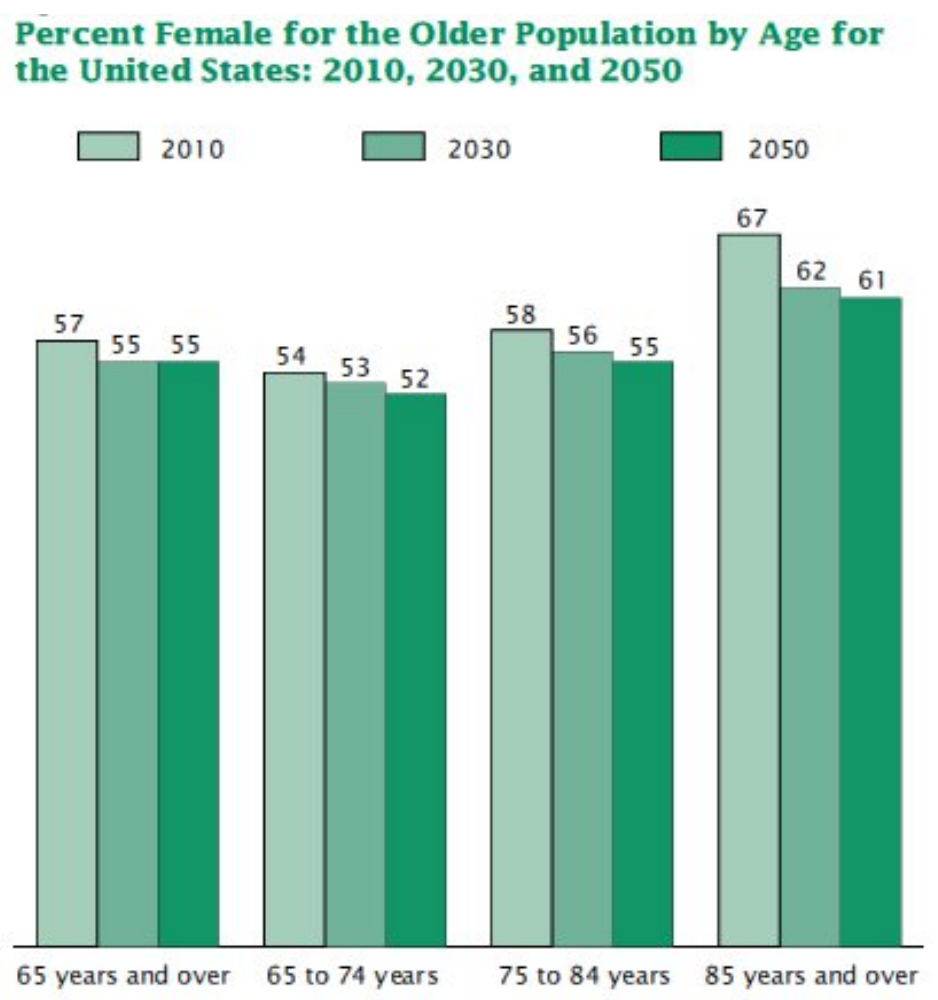

The preceding chart (Figure 4) shows the declining ratio of men to women in ascending age cohorts. The most recent life expectancy tables show a 4.1 year gender difference for 40-year-olds and an even larger gap of 4.4 years at age 30 . (The disparity is greater for blacks than for the population generally. $)^{40}$

It follows as a straightforward consequence that Social Security benefits paid to those over age 60 (widow and widower benefits) or those over age 62 (Old-Age Insurance or retirement benefits and spouse benefits) are received by more women than men. The percentage of women on the Social Security benefit rolls increases by age in close parallel with the chart above. ${ }^{41}$ And since these are benefits one cannot outlive, indeed, benefits that 
are adjusted upward over time as living costs rise, differences in longevity translate directly into differences in benefits received. On average, the same monthly benefit amount will have greater value for a woman than for a man because it will be paid over several more years. But, of course, men and women do not, on average, have the same benefit amounts.

The average monthly benefit paid senior women in December 2010 (averaging across all benefit types) was $74.5 \%$ that paid senior men. ${ }^{42}$ A principal source of the disparity is obvious. Because of their direct tie to the individual's history of earnings over an extended period, Social Security's retirement benefit amounts are dramatically lower for women than they are for men. In December 2010, the average retired worker benefit for women was $77.3 \%$ that for men. ${ }^{43}$ Over the years during which current beneficiaries compiled their Social Security earnings records, women received lower earnings than men, were more frequently engaged in part-time rather than full-time employment, and spent more years out of covered employment. ${ }^{44}$ (Social Security retirement benefits are based on indexed covered earnings over a 35-year period. With a period of potential work that can stretch from before age 22 past age 62, this formula will exclude five or more low or no earnings years. However, a lengthy period devoted to child rearing, care for adult relatives, or other non-market activity will have a direct impact on benefit amount.)

Since past and present marital relationships can be the basis for Social Security benefits, the distribution of marital status among those close to or past the age of eligibility is significant, with death of one partner becoming an factor of growing importance as age increases.

Because of their greater longevity and the typical age gap between spouses ${ }^{45}$ women are far more likely than men to fall in the widowed category. Over half the women 75 and over are widows, as are close to a quarter of those $65-74 .^{46}$ The percentage of seniors living alone increases with age. In the population 65 and over, the number of women living alone is 2.5 times the number of men who do. In the population 85 and over, the ratio is $3: 1 .{ }^{47}$

\section{Implications of these demographic realities for Social Security revision}

Due to increased labor force participation the percentage of women above Social Security's age of eligibility receiving retired worker benefits has grown steadily. ${ }^{48}$ While this has reduced the number of women receiving spouse benefits alone, because of the terms on which benefits are available to spouses, particularly the formula which furnishes a widow total benefits that are equal to those of her deceased husband, the principal effect has been an increase in the number of "dually entitled" beneficiaries. These are individuals receiving retirement benefits on their own account plus a spouse benefit supplement. See Figure 5. 
Figure $5^{49}$

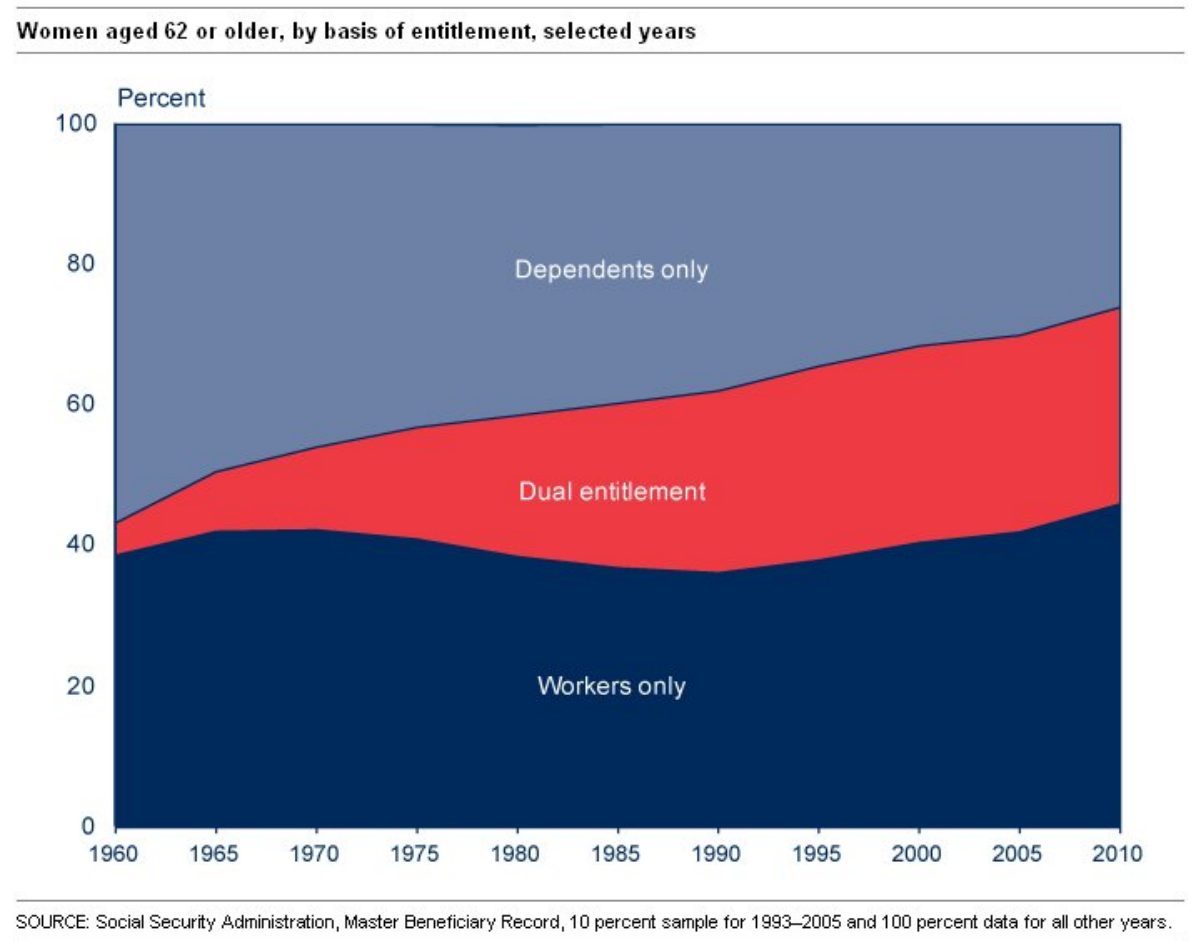

Women who have never been married or whose marriage or marriages ended in divorce before lasting 10 years are not eligible for wife or widow benefits. Nor are those whose own retired worker benefits exceed those payable on the account of their deceased husband or former husband. It is the case, however, that those groups represent a small, though growing, fraction of older women. The greater number of women currently receiving retired worker benefits but no spousal supplement are those with a living husband (or former husband). For them it is either the continued earnings of that husband or the amount of their own retirement benefits that precludes receipt of wife benefits. In short, these are women who will in future years, more likely than not, become dually entitled - when they are widowed, if not before. The average benefit paid to women receiving widow benefits (either widow benefits alone or, more dramatically still, widow benefits along with their own retired worker benefits) is substantially higher than that for women receiving only a retired worker benefit. ${ }^{50}$

In sum, any shift of retirement benefits and their spousal derivatives from the current progressive benefit program to a more strictly contributory scheme would disproportionately disadvantage women. Since women are, on average, more totally dependent then men on Social Security, prospective benefit reductions will seemingly have greater impact on them. Furthermore, treatment of marriage and divorce, as well as the existence and terms of spouse survivorship rights, by Social Security and within any new personal account scheme has particular importance for women.

Nonetheless, as important as spouse and surviving spouse benefits are to older women as a class and even to many of the most vulnerable among them, the law governing 
allocation of those benefits (that is the eligibility rules and the formulae setting their amount) is rife with arbitrariness and inequity. To observe that abolition or even dramatic curtailment of spouse benefits would have serious negative consequences for women is not to embrace the status quo, and emphatically not to advocate increasing the flow of benefits through that system.

\section{H. Social Security and race}

Social Security can be conceived of as consisting of three components: a) one providing annuities to retired workers and their surviving spouses, if any; b) one providing life insurance to younger workers with families; and c) one insuring against an interruption of employment income due to the onset of physical or mental impairments. The relative importance of these components is quite different for blacks, other minorities, and whites.

Of the whites receiving Social Security benefits in 2009, nearly eight in ten were retired workers, spouses of retired workers, or surviving spouses. ${ }^{51}$ Nearly seven in ten new benefits awarded whites that year fell in those categories. The comparable figure for blacks was fewer than five in ten. ${ }^{52}$ Death and disability strike young black workers disproportionately with the result that more than $40 \%$ of the Social Security benefits awarded blacks in 2009 were based on disability. Nearly one in ten went to children of deceased workers. ${ }^{53}$ The comparable figures for whites were significantly lower. Blacks, who comprise $13 \%$ of the working-age population, are $17 \%$ of Disability Insurance recipients. Black children comprise $15 \%$ of the population under 18 , but $22 \%$ or more of the recipients of child survivor benefits. ${ }^{54}$

Assertions that minorities are disadvantaged by Social Security typically focus only on Social Security's retirement piece, arguing that since minorities have shorter life expectancies on average they receive smaller returns. During the height of the 2005 press for action on President George W. Bush's Social Security plan, it was reported that "White House official and Republican strategists" began "a push to persuade AfricanAmericans and Hispanics that Social Security, long thought to be of benefit to them, is a bad deal." 55 In the context of a campaign for a personal account "carve out" this was misleading. To begin, the earnings gap between minority and majority workers is large, and the progressive benefit structure of Social Security delivers, on average, higher returns to any group with lower incomes. When one adds in the disability and survivors benefit components of Social Security, it becomes very difficult to make the case that Social Security's rate of return is lower for blacks and Hispanics than it is for non-Hispanic whites.

\section{Other groups with distinct interests in Social Security (and thus Social Security change)}

\section{Young, old, and in-between}

Those who reached retirement age in the early 1980s received a large net transfer. Members of that cohort who are still alive continue to do so. Their benefit levels substantially exceed any pensions their contributions plus interest would have funded. That was not true for the cohort reaching retirement age in 1990 nor is it true for those retiring this year or ten years from now. Under current law workers born after 1936 
are, on average, scheduled to receive benefits that represent less than a market rate of return on their tax contributions. ${ }^{56}$ Issues of intergenerational transfer and fairness surround all options for Social Security's future. Consider, for example, how the option of leaving the current law in place unchanged would affect those currently forty-six and younger (i.e. born after 1966 and hitting the age of 67 in 2033 or later). After paying the same levels of tax as their parents' generation now in their sixties this younger group would retire to benefits 25 percent or so below the nominal amount held out by today's statutory formula on account of inadequate program revenues projected for the point of their retirement and thereafter. ${ }^{57}$

Concern about disrupting the plans of those with relatively few years before retirement and related political considerations lead most solvency proposals to exempt not only current recipients but older workers as well from benefit adjustments. Such restraint inevitably shifts more of the burden of change onto younger cohorts. That is a major reason why delay has consequences for intergenerational equity.

\section{High-earnings, medium-earnings, and low-earnings workers}

On both its tax and benefit sides Social Security treats higher income workers and lower income workers differently. Its tax bite is lighter for those whose earnings exceed the annual earnings cap (\$106,800 for 2012) and those for whom earnings are not the sole source of income - groups that have a lot of overlap. On the other hand, these regressive features are counterbalanced by a benefit formula that provides better replacement rates for low than for medium earnings history retirees, and better replacement rates for those with average earnings histories than for those with higher ones. The federal income tax treatment of benefits reflects a similar progressive tilt.

Changes to Social Security designed to increase revenues or reduce long-term benefits almost invariably threaten the current balance between equity (comparable returns on contribution) and adequacy (higher return to those in greater need).

\section{A Possible Fundamental Change - Personal Accounts}

A core element of all plans put forward by the Bush Administration was the inclusion of voluntary personal accounts. (This was a requirement President Bush laid on his 2001 commission.) For a worker electing to establish such an account the idea was that there would be a Social Security offset (sometimes referred to as a "carve out"), i.e. the worker would pay a reduced Social Security tax and ultimately receive reduced Social Security retirement benefits. (Other plans have proposed adding government encouraged and administered personal accounts on top of Social Security, a very different matter.)

There are, of course, threshold questions such as whether some form of governmentinduced, regulated, and administered personal retirement account system should be added to Social Security either on top of or as a partial substitute for current benefits. There is the further question whether such a change is desirable in the context of concern over the program's long-term solvency. (Few proponents of personal accounts would contend that they represent a near term solution to the solvency problem.) Personal accounts are viewed variously as: a) an important component of any solvency solution that includes prospective benefit reduction, b) a sideshow or distraction, or c) a step in the 
wrong direction. In addition to the fundamental questions surrounding any proposal to add personal accounts to Social Security are numerous critical matters of detail. ${ }^{58}$

Of particular importance to the future of Social Security are issues concerning the interaction between personal accounts and “traditional” Social Security. Important details of any personal account scheme include:

- If it is voluntary, what does voluntary mean? Can the individual worker decide whether to allocate sums to a personal account each year (and if so how much) or are these to be irreversible one-time elections? The Bush proposal appeared to be the latter.

- How much can one allocate to this account each year? And is this allocation on top of or a “carve out” from current Social Security taxes? President Bush's proposed plan would have ramped up to an allocation of $4 \%$ of covered earnings "carved out" of Social Security taxes, subject to an initial maximum of $\$ 1,000$. The 2001 commission report offered three different plans: Model 1 ( $2 \%$ of covered earnings), Model 2 (4\% of covered earnings subject to a $\$ 1,000$ cap), and Model 3 (a worker contribution of 1\% of covered earnings on top of the Social Security tax, to be matched by a Government contribution of 2.5\%).

- How are traditional Social Security retirement benefits to be adjusted for those who have personal accounts? The dominant approach being discussed in 2005 consisted of an offset (often termed a "clawback") based on a hypothetical or "shadow" account. At the time for calculation of Social Security benefits the sums diverted to the individual's personal account increased by some stipulated interest rate compounded would be converted into a hypothetical annuity. The amount of that hypothetical annuity would then be subtracted from the person's Social Security benefit. (If you think the current benefit formula is hard to understand, consider trying to work this one through.)

With a voluntary account scheme workers would have to understand all of this well enough to decide whether to participate or leave the full amount of their contributions within Social Security. The percentage rate underlying the clawback is a critical parameter. The lower it is set the more attractive personal accounts will seem (thus, increasing the incentive for workers to establish one), but lower rates also mean reduced long-term savings to the Social Security system through the addition of personal accounts. If the rate is set lower than the yield of the federal bonds held by the Social Security trust funds, the difference can fairly be viewed as an implicit subsidy of personal accounts and at odds with the "higher return" rationale for such a plan. The clawback in the proposal the Bush White House was pursuing used an interest rate of $3 \%$ above inflation. The three options set out in the 2001 Commission report used rates of 3.5\% (Model 1), 2\% (Model 2), and 2.5\% (Model 3) above inflation.

A person electing to establish a personal account would receive higher total benefits if and only if the personal account realized a better net return than assumed in the clawback shadow account. One careful study concluded that a significant fraction of personal accounts would not be likely to achieve sufficient returns to offset the corresponding Social benefit reductions if premised on a 3\% above inflation interest figure. $^{59}$ 
Other important features of any personal account plan include details of administration, fees, and the permitted range of investment choices. The closest existing approximation of the scheme President Bush had in mind is the Thrift Savings Plan (TSP) available to federal employees and members of the military. ${ }^{60}$ The TSP is, however, a supplementary personal account program not an offset to federal pensions or Social Security. Moreover, while it may offer a relevant model, there are numerous dimensions for disagreement, discussion, and, if implemented, individual decision-making. Less conspicuous during the past "personal account" debate were a series of "ownership" questions.

\section{A. Spousal rights}

Spouse benefits are an important, if seriously flawed, feature of Social Security. Benefits paid over half of all women recipients include at least a portion based on a past or present marital relationship. What rights would a noncontributing spouse have in a worker's personal account? If the recommendations of the President's Commission of 2001 were followed, spousal rights would be even more concrete than they are in the Thrift Savings Plan (where they are, in general, more robust than with private sector retirement pensions). The Commission Report stated: “All account balances attributable to contributions during marriage, and all earnings on account balances brought into marriage, should be divided equally in the event of divorce.”" ${ }^{\text {"1 }}$ It went on to recommend that the personal account payout for all married individuals be in the form of a "two-thirds joint and survivor annuity" unless "both spouses agree.,"62

\section{B. Pre-retirement access}

President Bush explicitly embraced his Commission's recommendation on this point. A White House Document entitled "Strengthening Social Security for the $21^{\text {st }}$ Century" (February 2005) stated: "American workers who choose personal retirement accounts would not be allowed to make withdrawals from, take loans from, or borrow against their accounts prior to retirement." (Social Security's evolving approach to the definition of retirement and retirement age illustrates the potential complexity of this seemingly straightforward principle.) The scheme did contemplate that if a worker died before retirement heirs would have immediate access to the account. ${ }^{63}$

\section{Payout options}

The 2001 Commission Report also recommended limits on the form in which the account balance could be withdrawn upon retirement, preventing the holder, in most cases, from taking any portion out as a lump sum. ${ }^{64}$ As noted above the rules governing payout options would presumably, in the case of a married couple, take account of the circumstances of both spouses not simply the account holder.

\section{Dealing with the immediate impact of the reduced Social Security tax (FICA/SECA) payments}

The reduction in Social Security benefits resulting from workers making payments into personal accounts (clawback) would take place in the future. The corresponding loss of Social Security tax revenues would begin at once. The oldest workers permitted to 
contribute under the Bush proposal would have been 54, eight years from the Social Security age of eligibility, twelve years from their Full Retirement Age under current law. Substantial reductions in Social Security payout as a consequence of private accounts would not have come until years later as younger workers hit retirement age.

Meanwhile, every dollar going into a private account would be a dollar not available to cover program outflows. This lag between the revenue and benefit impact of personal accounts gives rise to "transition costs" ("investment costs" to supporters), the need to find additional revenue (or benefit reductions) for Social Security to replace the lost taxes.

\section{E. Implications for the non-pension components of Social Security}

As noted earlier, Social Security does far more than provide old-age pensions. Throughout the Bush-era political debate over personal accounts the implications of substituting personal retirement accounts for other portions of "traditional" Social Security remained unclear. Particularly unsettling was the seeming inattention to what this might mean for young covered workers who experienced an accident or injury preventing future employment (Disability Insurance) or who died leaving children, a surviving spouse, or dependent parent (survivors benefits). Social Security insures against such misfortunes through the same framework with which it provides a foundation for old-age income security. Currently, over one in ten new recipients of old-age benefits are not shifting from employment but instead transferring from Social Security's Disability Insurance program. ${ }^{65}$ Approximately one out of five individuals who receive Social Security payments are persons other than the worker on whose earnings those payments are based (20.8\%). And those payments total over one-fifth of the annual distribution of benefits by the program. (20.4\%). ${ }^{66}$ Vague assurances that the changes proposed for the program's old-age benefits would not affect these other elements were ultimately unpersuasive because of how integrally Social Security's different benefits are linked. ${ }^{67}$ The same benefit formula and similar coverage thresholds apply across all program components. It is nearly impossible to reform Social Security's old-age pension without also attending to disability, dependents, and survivors benefits. Furthermore, given the very limited political space available for adjusting Social Security's future revenues and future commitments in pursuit of long-term solvency and sustainability, it seems unwise to ignore revision of these non-pension components at the same time.

\section{Possible Changes That Would Address Social Security's Long-Term Fiscal Imbalance}

As suggested above, standing alone any personal account scheme that involves an immediate reduction in Social Security tax payments increases rather than diminishes the imbalance between the program's projected revenues and projected payout for a period of several decades. The benefit reductions from elections of personal accounts lie too far in the future to mitigate the negative effects of the program's shift from surplus generator to net payor around 2021 (or whatever the cash flow reversal year turns out to be) or the exhaustion of the program's nominal reserves around 2033. Consequently, if it is to address the solvency problem, a personal account proposal must be bundled with some combination of net downward adjustment of the program's benefit provisions (beyond those accompanying payments into personal accounts) and revenue increases. During the period he was actively pursuing Social Security revision, President Bush 
ruled out a prospective tax rate increase (though apparently not raising or removing the cap on earnings subject to the tax). From the start, his administration's emphasis was on the benefit side.

\section{A. Reducing future benefit payments}

\section{Price indexing replacing earnings indexing}

President Bush never got to the point of tabling a specific solvency plan, the Model 2 scheme presented by his 2001 commission, which most closely resembled his personal account proposal, provides an example of the kind of the program adjustments that might have been bundled with it. In that model the principal source of prospective benefit reduction was a shift in the PIA formula. For the current earnings indexing, it substituted price indexing. In all likelihood it would have shielded those 55 and older from the change, but for younger workers have operated on the current Primary Insurance Amount (PIA) formula of percentage multipliers. Here is how a footnote in the 2001 Commission Report explained this solution: "[T]he policy would be implemented by multiplying the PIA bend point factors (the bend points would remain indexed to wages) by the ratio of the Consumer Price Index to the Average Wage Index in successive years." 68

As presented by the Commission this would not constitute a "benefit reduction" since the revised formula would still generate benefits for future retirees with the same "purchasing power" or better in comparison with those received by present beneficiaries. In the Commission's words: “The new price-indexing policy slows the growth in future benefits. But, it ensures that future retirees will receive inflationadjusted benefits that are at least as high as the benefits received by today's retirees."69

This approach rejects the policy of maintaining stable replacement rates or ratios that underlies the “decoupled” benefit formula enacted in 1977. Measured in replacement rate terms the change would have constituted a major reduction for future retirees. Rather than providing retirement benefits in a relatively stable ratio to pre-retirement earnings (albeit ratios that are different for those at different earnings levels) this change would lead to steadily declining ratios - assuming, of course, that wages continue to grow faster than prices. Proponents argue that earnings-indexing represents unsustainable benefit growth and a shift to price-indexing, since it provides future retirees with benefits of comparable purchasing power, is not a benefit cut. ${ }^{70}$

Low-income workers would, of course, be most threatened by a change of this sort. Anticipating the concern, the Commission's Model 2 package included an increase in the minimum benefit for steadily employed low-income workers "relative to the price indexed benefit level.” Its target was a benefit significantly above the poverty level for "a 30year minimum wage worker."

One member of the 2001 Commission, Robert Pozen, achieved visibility in March of 2005 with a plan he labeled “progressive indexation.” It would have retained wage indexing for low-earnings workers, shifted to price indexing for the highest group, and employed a blend of the two for those in the middle. ${ }^{71}$ 


\section{Alternative avenues toward fiscal relief through reducing benefits for future retirees}

Other forms of future benefit reduction receiving attention during recent Social Security policy debates include: a) continuing the upward adjustment of Full Retirement Age beyond age 67 and/or speeding up the increase to 67, and b) automatically decreasing the Primary Insurance Amount (PIA) as life expectancies increase (longevity indexing). Additional options are: a) shifting to a less generous and arguably more accurate annual cost-of-living adjustment, b) changing the PIA formula to include more years, c) reducing the multipliers in the PIA formula for the top band(s).

\section{B. Increasing program revenues}

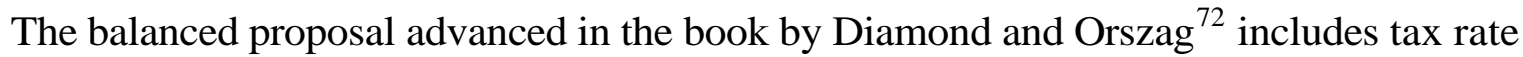
increases, which as noted above President Bush categorically ruled out and have not figured in more recent plans. Many have urged bringing those state and local government employees who still remain outside Social Security under the program. Other options including raising or removing the cap on the range of earnings subject to the Social Security tax (with or without including those earnings in the benefit formula) and increasing the amount of Social Security benefits subject to the income tax.

Finally, there are general revenues (perhaps, drawn from a restored and reinvigorated estate tax). The two model plans in the 2001 commission report that achieved or approached solvency while adding personal accounts turned to general revenues to cover program short-falls. In significant part those short-falls were, under Models 2 and 3, the product of their shifting Social Security tax revenues from the funding of current benefits to advance funding of personal accounts. This allowed those supporting Model 2 to argue that these general revenue infusions might be viewed in loan-like terms:

In order to maintain the ability to pay benefits throughout the 75-year period, additional revenue would likely be needed (in years 2025 through 2054 under the assumptions used for these estimates). The Reform Model would provide for transfers from the General Fund of the Treasury in amounts needed for such years. However, because of substantial expected cash flow surpluses later in the period, and beyond, these transfers could be repaid. ${ }^{73}$

The Pozen plan (see III.A.1 above) explicitly called for general fund transfers totaling \$1.9 trillion in present value between 2030 and 2078, estimated to produce a trust fund balance of $\$ 200$ billion and positive cash flow by 2078 . $^{74}$

\section{Other Program Changes That Might Be Bundled}

\section{A. Surviving spouse benefits}

Two of the three plans put forward by the President Bush's 2001 commission recommended a change in the benefits for widows and widowers, a change that would assure the survivor a benefit equal to $75 \%$ of the combined Social Security payments received by the couple while both were alive. No further details were furnished. ${ }^{75}$ 
Current law falls short of that amount. It provides somewhere between $66 \%$ (when death brings a shift from $100 \%$ of PIA plus a spouse benefit of $50 \%$ to a surviving spouse or retired worker amount of 100\%) and 50\% (the case where both spouses had similar earnings records and were therefore receiving near equal retirement benefits). These percentages vary, of course, if the spouses begin benefits at different ages.

Important as the spouse benefit structure is for women, using it as the principal instrument for addressing issues of gender equality and benefit adequacy for older women has serious and growing problems. The equity issues are huge. In addition, because of declining marriage rates and the prevalence of divorce following fewer than ten years of marriage, it is likely that in successive cohorts of senior women, fewer and fewer will be eligible for these dependent benefits. ${ }^{76}$ Because these trends are particularly pronounced among black women, any enhancement of widows' benefits will result in greater racial disparity. ${ }^{77}$

Other program adjustments have the potential for improving benefits for women without tying that improvement to past or present marriages.

\section{B. A benefit increment for very old recipients}

Two plans put forward in 2010 as part of comprehensive deficit reduction proposals included a benefit increment for long-term recipients. ${ }^{78}$ The idea responds to the high levels of poverty among the oldest Social Security recipients, the majority of whom are women. Having outlived other financial resources, these beneficiaries are uniquely dependent on Social Security.

\section{An improved benefit formula for low-earnings workers}

Any package of changes that includes future benefit reduction poses the greatest threat to those whose earnings have little or no margin for additional retirement savings. The current Social Security formula has two forms of special protection for low-earnings workers: a) a PIA formula that provides higher earnings replacement for those with low average indexed monthly earnings, and b) a special minimum for those with long years of low earnings. Even so it generates benefits that fall below the poverty threshold for a single person household (65 or over). The gap is particularly pronounced for those who, often without choice, commence their benefits at age 62. Model 2 of the 2001 Commission report, while generally reducing earnings replacement by a shift to price indexing, contained an enhanced special minimum for low-earnings workers, aimed ultimately at delivering a benefit equal to $120 \%$ of the poverty level to a 30 -year minimum wage worker. Model 3 included a similar feature with a $100 \%$ target. $^{79}$ Most subsequent plans have contained a benefit formula adjustment designed to assure minimally adequate retirement income to steadily employed low-earnings workers.

\section{The Framing of Reform}

Since the program's birth, success at establishing the language and the concepts framing Social Security features and options has held immense political importance. Whenever hard choices about the system were thrust upon an administration and Congress, those who proved able to define the starting point and the units of analysis attained the upper hand. Since the political environment surrounding Social Security 
finds cuts unpopular, if not inconceivable, finding a way to present change as stability provides enormous advantage. Success in framing the adequacy of future benefits in terms of "replacement rate" helped establish wage-indexing in $1977 .{ }^{80}$ The prospective benefit reduction enacted in 1983 was packaged as a gradual increase in what is now termed the "Full Retirement Age."

In 2005 negative public sentiment about "privatizing Social Security" led the Administration to insist that President Bush be understood as proposing "personal accounts" and opponents with equal persistence to characterize the President Bush's plan as one of "private accounts" or "privatization." ${ }^{21}$ The Bush Administration failed to build public or political acceptance of the terms or concepts within which his preferred package of changes could be viewed as not only palatable but desirable. The commission Bush established during his first term failed to reach consensus on a single plan or rhetorical/conceptual approach around which bipartisan support could be built.

One basis for preferring "longevity indexing" over further adjustment of the "Full Retirement Age" is a belief that the terminology relates more clearly to a coherent rationale for ongoing benefit formula revision. Similarly, shifting to a different and "more accurate" measure of the impact of price inflation on beneficiaries should be more saleable than simply subtracting a percentage point from the current formula.

A broad concern over the federal debt and the nation's fiscal future now frames most discussion about Social Security. There can be little doubt that the topics are connected. However, the risk this poses is that enduring changes to Social Security may be enacted as part of some grand bargain over spending cuts and revenue increases. That may avert a federal budget crisis. However, it will, very likely, fail to do justice to the challenging issues embedded within this singular program, which touches the lives and household budgets of nearly all Americans. Social Security's current structure is the product of over seven decades of incremental amendment. Most of those changes were enacted at a time when ample program revenue made it easy for Congress to deal with any apparent inequity by expanding benefits or removing restrictions. Many reflect assumptions about work, family composition, and the other financial resources on which individuals and families depend that are a poor fit with contemporary conditions, let alone those likely to prevail into the future. To shrink the notion of Social Security reform to the balancing of its long-term income and costs would be to throw away a rare opportunity to make other needed structural changes.

\footnotetext{
* (C) Peter W. Martin, 2012. This work is licensed under the Creative Commons Attribution-NoncommercialShareAlike 3.0 License. To view a copy of this license, visit http://creativecommons.org/licenses/by-ncsa/3.0/ or send a letter to Creative Commons, 543 Howard Street, 5th Floor, San Francisco, California, 94105, USA.

** Jane M.G. Foster Professor of Law, Emeritus, Cornell Law School, Ithaca, New York and author of Martin on Social Security, an electronic reference work first published in 1990 and now accessible at: http://social-security-law.wikispaces.com/.

${ }^{1}$ See Stephen C. Goss, Chief Actuary, Social Security Administration, Testimony before the House Committee on the Budget, U.S. House of Representatives (Feb. 28, 2012).

${ }^{2}$ The 2011 special minimum benefit Primary Insurance Amount (PIA) for a 30-year worker was \$763.20.
} 
The standard formula yielded a PIA of $\$ 903.10$ for a worker steadily employed at the federal minimum wage and a PIA of $\$ 1,012$ for an individual whose earnings were one-half the national average throughout a working lifetime. See Social Security Benefit Tables, http://www.socialsecurity.gov/OACT/ProgData/tableForm.html; . See generally Kelly A. Olsen \& Don Hoffmeyer, Social Security's Special Minimum Benefit, 64 Soc. SEC. Bull., Sept. 2002, at 1, available at https://www.socialsecurity.gov/policy/docs/ssb/v64n2/v64n2p1.pdf.

${ }^{3}$ See Bipartison Policy Center, Restoring America’s Future 80 (2010), http://bipartisanpolicy.org/projects/debt-initiative/about (hereinafter Domenici-Rivlin Report). The poverty threshold for a single aged individual in 2011 was $\$ 10,788$. See U.S. Census Bureau, Poverty Thresholds, http://www.census.gov/hhes/www/poverty/data/threshld/index.html.

${ }^{4}$ See Frank Newport, Six in 10 Workers Hold No Hope of Receiving Social Security, Gallup Politics, July 20, 2010, http:// www.gallup.com/poll/141449/Six-Workers-Hold-No-Hope-Receiving-Social-

Security.aspx.

${ }^{5}$ Throughout the first half of his presidency, President George W. Bush pressed the need for "Social Security reform.” In his first term he appointed a Social Security Commission and charged it with devising a path to sustainability that would include individually funded accounts. The commission issued a report in December 2001, but failed to endorse a single plan. See Final Report of the President's Commission to Strengthen Social Security (2001), http://govinfo.library.unt.edu/csss/reports/Final_report.pdf (hereinafter Bush Commission Report). At the beginning of his second term, President Bush led conversations on "Strengthening Social Security" across the country. By then he spoke less of a particular plan, and more of the urgent need to solve the program's fiscal problem and some ideas he had put before Congress, including optional "personal savings accounts" for younger workers. Said he about those in the legislative branch, of both parties, "[I]f they've got a better idea, bring them forward." But consensus failed to emerge and by late 2005 the topic had largely disappeared from both public view and political exchange.

President Obama appointed a Commission on Fiscal Responsibility and Reform in 2010. Its report, which included a Social Security sustainability plan, failed to secure the support of the necessary "super majority" of members to become a formal recommendation. See President Obama's Fiscal Commission Report (2010), http://www.ssa.gov/history/reports/ObamaFiscal/ObamaCommission.html (hereinafter SimsonBowles Report).

Later, during a brief period in 2011 when President Obama held out hope of reaching agreement with Congress on a deficit reduction plan that would include tax increases he expressed a willingness to consider changes in Social Security as part of the broader agreement. See In debt talks, Obama Offers Social Security Cuts, WASHINGTON POST, July 6, 2011, http://www.washingtonpost.com/business/economy/in-debt-talksobama-offers-social-security-cuts/2011/07/06/gIQA2sFO1H_story.html. When that effort at negotiation failed, he withdrew the offer. The White House explained that since Social Security was not a contributing factor to near-term deficits its issues ought to be addressed separately. See Obama Won't Include Social Security Reform in Recommendations to Super Committee, HufFInGTON Post, Sept. 15, 2011, http://www.huffingtonpost.com/2011/09/15/obama-social-security_n_964175.html.

${ }^{6}$ The Social Security Advisory Board is an independent bipartisan body created by the Congress and appointed by the President and the Congress that is charged with advising the President, the Congress, and the Commissioner of Social Security.

${ }^{7}$ See Social Security Advisory Board, Social Security: Why Action Should Be Taken Soon 15 (2010), http://www.ssab.gov/Documents/Sooner_Later_2010.pdf.

${ }^{8}$ See The 2007 Annual Report of the Board of Trustees of the Federal Old-Age and Survivors Insurance and Federal Disability Insurance Trust Funds 2, available at http://www.ssa.gov/oact/tr/2007/ (hereinafter 2007 Social Security Trustees Report).

${ }^{9}$ Stephen C. Goss, Chief Actuary, Social Security Administration, Testimony before the House Committee on Ways and Means, Subcommittee on Social Security, Figure 8 (Dec. 2, 2011), available at http://www.ssa.gov/legislation/testimony_120211.html. 
${ }^{10}$ See The 2011 Annual Report of the Board of Trustees of the Federal Old-Age and Survivors Insurance and Federal Disability Insurance Trust Funds 2, available at http://www.ssa.gov/oact/tr/2011/ (hereinafter 2011 Social Security Trustees Report).

${ }^{11}$ See The 2012 Annual Report of the Board of Trustees of the Federal Old-Age and Survivors Insurance and Federal Disability Insurance Trust Funds 2, available at http://www.ssa.gov/oact/tr/2012/ (hereinafter 2012 Social Security Trustees Report).

${ }^{12}$ Compare 2012 Social Security Trustees Report, supra note 11, at 38 with 2007 Social Security Trustees Report, supra note 8, at 33.

${ }^{13}$ Compare 2011 Social Security Trustees Report, supra note 10, at 41 with 2007 Social Security Trustees Report, supra note 8, at 38.

${ }^{14}$ See Letter from Stephen C. Goss, Chief Actuary, Social Security Administration, to Congressman Xavier Becerra, http://www.ssa.gov/oact/solvency/XBecerra_20120217.pdf.

${ }^{15}$ From 1994 through 2010 the projected deficit vacilated around 2\%. It was highest in 1997 at 2.23\%, lowest in 2008 at 1.70\%. See 2011 Social Security Trustees Report, supra note 10, at 150.

${ }^{16}$ The 2011 report placed that figure at 2.22\%. See 2011 Social Security Trustees Report, supra note 10, at 12. The 2012 report raised the estimate to 2.67\%. See 2012 Social Security Trustees Report, supra note 11, at 14 .

${ }^{17}$ See Peter A. Diamond \& Peter R. OrsZag, Saving Social Security: A Balanced Approach 3435 (2004). Of all the recent writing about Social Security's financing challenge and options, this book is one of the most useful.

${ }^{18}$ See 2012 Social Security Trustees Report, supra note 11, at 15.

${ }^{19}$ See 2012 Annual Report of the Boards of Trustees of the Federal Hospitalization Insurance and Federal Supplementary Medical Insurance Trust Funds 7, available at https://www.cms.gov/ReportsTrustFunds/downloads/tr2012.pdf (hereinafter 2012 Medicare Trustees Report)..

${ }^{20}$ See id.

${ }^{21}$ See 2012 Social Security Trustees Report, supra note 11, at 8, 16.

${ }^{22}$ See 2012 Social Security Trustees Report, supra note 11, at 63. In fact, just a year before the low-cost assumption projection showed a positive actuarial balance. See 2011 Social Security Trustees Report, supra note 10 , at 63 .

${ }^{23}$ Congressional Budget Office, The Outlook for Social Security (2004), http://www.cbo.gov/sites/default/files/cbofiles/ftpdocs/55xx/doc5530/06-14-socialsecurity.pdf.

${ }^{24}$ As the trustees' annual reports routinely note:

Future income and expenditures of the OASI and DI Trust Funds will depend on many factors, including the size and characteristics of the population receiving benefits, the level of monthly benefit amounts, the size of the workforce, and the level of covered workers' earnings. These factors will depend in turn on future birth rates, death rates, immigration, marriage and divorce rates, retirement-age patterns, disability incidence and termination rates, employment rates, productivity gains, wage increases, inflation, interest rates, and many other demographic, economic, and program-specific factors.

2012 Social Security Trustees Report, supra note 11, at 8.

${ }^{25}$ GAO Report: Social Security: Criteria for Evaluating Social Security Reform Proposals, T-HEHS-99- 94, at 4. (Mar. 25, 1999).

${ }^{26}$ See 2012 Social Security Trustees Report, supra note 11, at 30.

${ }^{27}$ See id. 
${ }^{28}$ See id. at 3, 43.

${ }^{29}$ Douglas Holtz-Eakin, Director, Congressional Budget Office, Statement before the Special Committee on Aging, United States Senate 2-3 (Feb. 3, 2005).

${ }^{30}$ In a "Policy Brief" entitled “The Distributional Consequences of a 'No-Action' Scenario: Updated Results” Social Security Administration's Office of Retirement Policy worked from the premise that since the trust funds are projected to be exhausted in 1941 "All beneficiaries would have their scheduled benefits cut by 27 percent in 2042." However, the first footnote concedes that "a proportionate cut ... is only one possible option for allocating benefit reduction among beneficiaries." See http://www.ssa.gov/policy/docs/policybriefs/pb2005-01.pdf.

312012 Medicare Trustees Report, supra note 19, at 8.

${ }^{32}$ Id. at 2-3, 8.

${ }^{33}$ See Office Management and Budget, Historical Tables, Table 2.3, http://www.whitehouse.gov/omb/budget/Historicals.

${ }^{34}$ See 2012 Social Security Trustees Report, supra note 11, at 3.

${ }^{35}$ DiAMOND \& ORSZAG, supra note 17.

${ }^{36} I d$. at 84 .

${ }^{37} I d$. at 88 .

${ }^{38}$ See Debt Reduction Task Force, Bipartisan Policy Center, Restoring America’s Future 70-83 (2010) (hereinafter Domenici-Rivlin Plan), available at http://bipartisanpolicy.org/projects/debt-initiative/about; Simson-Bowles Report, supra note 5.

${ }^{39}$ Census Bureau, The Next Four Decades - The Older Population in the United States: 2010 to 2050, at 8 (May 2010), available at http://www.census.gov/prod/2010pubs/p25-1138.pdf.

${ }^{40}$ Elizabeth Arias, United States Life Tables, 2007, 59 National Vital Statistics Reports, No. 9, at 2 (National Center for Health Statistics 2011).

${ }^{41}$ In December 2010, the portion of Social Security recipients who were female was $53.1 \%$ for the age range $65-69,55.7 \%$ for the age range $75-79,64.7 \%$ for the age range $85-89$ and $72.3 \%$ for the age range $90-99$. See Social Security Administration, Annual Statistical Supplement, 2011, Table 5.A10 (hereinafter 2011 Annual Statistical Supplement).

${ }^{42} \$ 995.40$ for women 60 or older compared to $\$ 1,321.10$ for men 60 or older. Id.

${ }^{43} \$ 1,022.90$ for women compared to $\$ 1,323.10$ for men. Id.

${ }^{44}$ See P. Levine, O. Mitchell, \& J. Phillips, A Benefit of One's Own: Older Women's Entitlement to Social Security Retirement, 67 SOC. SEC. BuLL., July 2001, at 47, available at http://www.ssa.gov/policy/docs/ssb/v63n3/v63n3p47.pdf.

${ }^{45}$ In over half of all married couples, the husband is 2 or more years older than the wife. In nearly one-third, the husband is 4 or more years older. See Census Bureau, Table FG4. Married Couple Family Groups, by Presence of Own Children/1 In Specific Age Groups, and Age, Earnings, Education, and Race and Hispanic Origin/2 of Both Spouses: 2010, http://www.census.gov/population/www/socdemo/hh-fam/cps2010.html.

${ }^{46}$ Census Bureau, Table 57. Marital Status of the Population by Sex and Age: 2010, http://www.census.gov/compendia/statab/2012/tables/12s0057.pdf.

${ }^{47}$ See Census Bureau, Table A2. Family Status and Household Relationship of People 15 Years and Over, by Marital Status, Age, and Sex: 2010, http://www.census.gov/population/www/socdemo/hhfam/cps2010.html.

${ }^{48}$ The climbing labor force participation of women has been a major factor in the growth of the population 
insured for Disability Insurance, and consequently the cost of that component of the program. See Stephen C. Goss, Chief Actuary, Social Security Administration, Testimony before the House Committee on Ways and Means, Subcommittee on Social Security (Dec. 2, 2011).

${ }^{49}$ Social Security Administration, Fast Facts and Figures About Social Security 21 (2011), available at http://www.ssa.gov/policy/docs/chartbooks/fast_facts/2011/fast_facts11.pdf.

50 See 2011 Annual Statistical Supplement, supra note 41, Table 5.A15.

${ }^{51}$ See id. Table 5.A1.

${ }^{52}$ See id. Table 6.A3.

${ }^{53}$ See id.

54 See DiAMOND \& ORSZAG, supra note 17, at 174-75.

${ }^{55}$ Edmund L. Andrews, G.O.P. Courts Blacks and Hispanics on Social Security, New York Times, March 20, 2005, at A 24.

${ }^{56}$ Diamond \& Orszag, supra note 17 , at 70-72. This is not to say that the proposition holds for all individuals within a given retirement cohort. It is very likely that the special minimum PIA for steadily employed low-income workers delivers an above-market rate of return. Those visited by disability or death at a young age also realize a positive benefit to contribution ratio, and for all covered workers the return in the form of Old-Age Insurance is enhanced by Social Security’s insurance against these other contingencies.

57 See 2012 Social Security Trustees Report, supra note 11, at 10-11.

${ }^{58}$ See Virginia P. Reno et al., Uncharted Waters: Paying Benefits from Individual Accounts in Federal Retirement Policy (NASI 2005), http://www.nasi.org/research/2005/uncharted-waters-paying-benefitsindividual-accounts-federal.

${ }^{59}$ See Robert J. Schiller, Life-cycle Personal Accounts Proposal for Social Security: An Evaluation of President Bush’s Proposal (2005), available at http://www.econ.yale.edu/ shiller/pubs/life-cycle2006.pdf. The report by Robert J. Schiller was summarized in the Washington Post for March 19, 2005. Jonathan Weisman, Retirement Accounts Questioned Paper Challenges Expected Benefits, WASHINGTON POST, March 19, 2005, at E 1.

${ }^{60}$ For more information about the TSP go to http://www.tsp.gov/.

${ }^{61}$ Bush Commission Report, supra note 5, at 53.

${ }^{62}$ Id. at 54.

${ }^{63}$ See id. at 50.

${ }^{64}$ See id. at 51.

${ }^{65}$ See 2011Annual Statistical Supplement, supra note 41, Table 6.B.5.1.

${ }^{66}$ See 2011Annual Statistical Supplement, supra note 41, Table 4.A5, Table 4.A6, Table 5.A1.

${ }^{67}$ President Bush indicated in a January 2005 interview with the Washington Post that his reform plan did not entail changes in Social Security disability or survivors benefits. Jim VandeHei \& Michael A. Fletcher, Bush Says Election Ratified Iraq Policy; No U.S. Troop Withdrawal Date Is Set, WASHINGTON Post, Jan. 16, 2005, at A 1.

68 Bush Commission Report, supra note 5, at 109, n. 42.

${ }^{69}$ Id. at 109.

${ }^{70}$ Years ago this author abserved in connection with 1977 benefit formula revision: "If future benefits are compared to present payments or to the gross national product, wage-indexing appears to commit the system to growth whereas price-indexing yields stability. On the other hand, when the criterion of 
replacement rate is used, wage-indexing appears to maintain a stable benefit level while price-indexing leads to gradual shrinkage - higher benefits but lower replacements rates. Supporters of the 1977 Congressional wage-indexing scheme characterized it as the path of stability; opponents viewed it as a commitment to benefit growth. Both were right.” Peter W. Martin, The Art of Decoupling: Keeping Social Security's Promise Up-to-Date, 65 CORNELl L. ReV. 748, 788 (1980) (citations omitted).

${ }^{71}$ Pozen's plan is detailed in a memorandum to him dated Feb. 10, 2005 from SSA's chief actuary Stephen Goss, http://www.ssa.gov/OACT/solvency/RPozen_20050210.pdf (hereinafter Goss memo). It was mentioned by the President at a March 16, 2005, press conference and subsequently became one of his Social Security reform discussion points. See Charles Stein, Pozen’s Social Security Fix Sparks Buzz, THE Boston Globe, March 17, 2005; Edmund L. Andrews, Republicans Consider Slowing Benefits Growth for Most, N.Y. Times, Mar. 25, 2005.

72 DiAmOND \& ORSZAG, supra note 17.

${ }^{73}$ Bush Commission Report, supra note 5, at 110.

${ }^{74}$ Goss memo, supra note 71 , at 7 and Table 1a.

${ }^{75}$ See Bush Commission Report, supra note 5, at 97.

${ }^{76}$ See I-Fen Lin \& Susan L. Brown, Unmarried Boomers Confront Old Age: A National Portrait, THE GERONTOLOGIST (2012).

${ }^{77}$ See Christopher R. Tamborini, Howard M. Iams \& Kevin Whitman, Marital History, Race, and Social Security Spouse and Widow Benefit Eligibility in the United States, 31 RESEARCH ON AgING 577 (2009); Madonna Harrington Meyer, Douglas A. Wolf, and Christine L. Himes, Linking Benefits to Marital Status: Race and Social Security in the US, 11 FEMINIST ECONOMICS 145 (2005).

${ }^{78}$ See Simson-Bowles Report, supra note 5, at 50; Domenici-Rivlin Plan, supra note 36, at 80.

${ }^{79}$ Bush Commission Report, supra note 5, at 14.

${ }^{80}$ Martha Derthick, POLICYMAKING FOR SOCIAL SECURITY 405 (1979).

${ }^{81}$ See Robin Toner, It's 'Private' vs. 'Personal' in Social Security Debate, N.Y. TimEs, Mar. 22, 2005. 


\section{Appendix}

\section{Social Security's Core Components, Terminology, and Points of Proposed Adjustment}

This summary of Social Security basics draws upon the author's Social Security Law reference work and related material, available at:

http://social-security-law.wikispaces.com/

\section{A. Program Revenues}

Under current law, nearly all revenue supporting Social Security comes from four sources: (1) Social Security taxes imposed on employment and self-employment income, (2) interest paid on U.S. Treasury bonds held by the two Social Security trust funds, (3) income tax proceeds derived from taxing Social Security benefits, and (4) reimbursement transfers from general revenues.

\section{(1) Social Security Taxes}

Under the Federal Insurance Contributions Act (FICA) both employees in covered work and their employers pay a tax of $6.2 \%$ on earnings up to an annual Maximum Taxable Amount. That cap on taxable earnings (which also limits the earnings counted toward benefits) is subject to annual automatic adjustment as national average earnings rise. The figure for 2012 is $\$ 110,100$. While not, strictly speaking covered by FICA, state and local governments that have elected to participate in Social Security and their employees pay equivalent amounts. The Self-Employment Contributions Act (SECA) imposes a tax equal to the combined employer-employee taxes of FICA on the net earnings of self-employed individuals.

Total revenue from these tax sources, often referred to collectively as the Social Security Payroll Tax, totalled $\$ 637.3$ billion in 2010, 82\% of program income. The amount was reduced for 2011 (and is reduced again during 2012) by a temporary subtraction of $2 \%$ from the employee and self-employed individual rate, enacted as a stimulus measure. The legislation providing for that reduction called for reimbursement from general revenues to make up for the resulting loss in Payroll Taxes.

The types of work covered by Social Security and subject to the Payroll Tax have been expanded time and again since the program was first established in 1935. Today, most work performed in the United States, as well as most work performed abroad by U.S. nationals, is covered. Work done in one's own business ("self-employment") and work done as an employee in someone else's business ("employment") both count. In contrast, forms of income that come to an individual without work, such as interest, dividends, gifts, and lottery winings, are not taxed.

\section{Possible Changes That Have Been Part of Recent "Sustainability" Proposals}

While private employers and their employees have no choice about coverage and exposure to the Payroll Tax, historically the coverage of state and local government employment has been voluntary. Today, the principal category of employees not covered 
and, therefore, not paying into Social Security are those working for units of state and local governments that have opted not to participate. Bringing those workers into Social Security (as they have been brought into Medicare) would, over the near term, increase program revenues and only later and over time increase program costs.

Other program changes contained in recent proposals that would increase Payroll Tax revenue include raising or eliminating the Maximum Taxable Amount. (The comparable tax supporting Medicare has no such limit.) Of course, the most direct approach would be to raise the tax rate, but there appears to be little appetite for that, particularly since, due to the temporary $2 \%$ reduction, the rate is already scheduled to increase at the end of the Payroll Tax "holiday" as it returns to 6.2\%.

Plans that include a private account component, either mandatory or voluntary, that would substitute for a portion of Social Security inevitably entail a reduction in near term Payroll Tax revenue in contemplation of an eventual decrease in program costs.

\section{(2) Interest Income from the Assets Held by the Two Trust Funds}

For decades Social Security revenue has exceeded program expenditures. The accumulating reserves, held in two trust funds, generate a second source of program income. Those reserves are invested in specially issued interest-bearing securities of the U.S. Government. During 2010, these earned an effective interest rate of 4.6\%, generating $\$ 117.5$ billion in income, 15\% of the total for that year.

\section{Possible Changes That Have Been Part of Recent "Sustainability" Proposals}

During earlier bullish days, there were proposals to increase the yield of the Social Security surplus by investing a portion of the trust funds in equities. More recent plans have not pursued the idea.

\section{(3) Income Tax Revenue Flowing from Taxation of Social Security Benefits}

Up to $85 \%$ of Social Security benefits are subject to the federal income tax. The revenue generated is allocated between Social Security and Medicare, with Social Security receiving the amount produced by taxing $50 \%$ of benefits. Only $3 \%$ of program revenues in 2010 came from this source, $\$ 23.9$ billion in total.

\section{(4) Tranfers from General Revenues}

Historically, general revenues have played a very limited role in Social Security funding. Typically Congress has authorized general fund reimbursement only when it has legislated benefits or benefit credits not resting on earnings that had been subject to the Payroll Tax (such as those granted for military service prior to 1982). During the recent recession, as Payroll Tax reductions have been enacted to provide economic stimulus without any compensating reduction in present or future benefits, reimbursement from general revenues has been substituted for the lost tax revenue. General revenue reimbursement constituted $\$ 2.4$ billion in 2010 (less than 1\% of that year's Social Security revenue). Reimbursement for the $2 \%$ payroll tax holiday throughout 2011 and 2012 will increase that amount. 


\section{Possible Changes That Have Been Part of Recent "Sustainability" Proposals}

A number of plans have proposed dedicating a discrete portion of the estate tax or restored income tax revenues to building up Social Security's reserves.

\section{B. The Trust Funds}

By law there are two separate accounts in the U.S. Treasury into which Social Security revenues are deposited and from which benefits and program administrative costs are paid. The Old-Age and Survivors Insurance (OASI) fund covers monthly benefits to retired-worker (old-age) beneficiaries, their spouses, and children and to survivors of deceased insured workers. The Disability Insurance (DI) fund covers benefits to disabled-worker beneficiaries, their spouses, and children as well as the cost of providing rehabilitation services to the disabled. Both trust funds are overseen by a Board of Trustees. That board consists of six members, four who serve automatically by virtue of their positions in the Federal Government, namely: the Secretary of the Treasury, the Secretary of Labor, the Secretary of Health and Human Services, and the Commissioner of Social Security. The other two are "public representatives" appointed by the President, subject to Senate confirmation. Among the duties of the Board of Trustees is the submission of an annual report to Congress on the status of the two trust funds.

\section{Program Costs}

Nearly all expenditures covered by the two Social Security trust funds are for benefits. The funds do also pay the costs of administering Social Security, but these constitute less than $1 \%$ of total annual expenditures.

\section{(1) Benefits}

Total benefit payments during 2010 were $\$ 701.6$ billion (against total revenue $\$ 781.1$ billion). At the end of February 2012 nearly 36 million individuals were receiving OldAge Insurance at a rate of $\$ 44.2$ billion per month; 8.6 million were receiving Disability Insurance at a rate of $\$ 9.6$ billion per month; and 11.2 million family members were receiving Auxiliary Benefits at a rate of nearly $\$ 9$ billion per month.

\section{(a) Categories of Social Security Benefits}

The Social Security program provides two types of benefits for the worker whose own earnings have established entitlement: 1) Disability Insurance benefits, available to covered workers who become severely disabled, and 2) Old-Age Insurance (retirement) benefits, available to workers 62 and over who meet the program's definition of retirement. Benefits received directly by the worker are sometimes called Primary Benefits. In addition to these two types of Primary Benefits, the Social Security program provides Auxiliary Benefits. These are benefits paid to children, spouses, former spouses, and parents of a covered worker under certain circumstances. Three different events in the worker's life can trigger such Auxiliary Benefits - retirement, disability, and death. Covered workers who have no family members falling into the 
eligible categories at those times get no return from this element of Social Security despite having made the same Payroll Tax payments as those who do. Auxiliary

Benefits received by children and spouses of Disability Insurance recipients are, like the primary benefits to which they relate, charged to the Disability Insurance trust fund. All others are charged to the Old-Age and Survivors Insurance fund.

Both eligibility for Social Security benefits and the monthly payments to beneficiaries depend on how much a working person earned in employment and self-employment covered and taxed by the Social Security system, over a period of years.

\section{(b) The Connection between Past Covered Work and Eligibility}

Although the different types of Social Security benefits have somewhat different standards, all depend on some person (either the claimant or the relative on whom his or her benefits rest) having sufficient covered earnings to have attained Insured Status. The requirement reflects the notion, which the program has carried from its inception, that benefits are payable only to those individuals or families who have paid into the system through the Payroll Tax during a significant period of covered work. All tests of Insured Status are expressed in terms of Quarters of Coverage, requiring a certain total of qualifying quarters or a certain number during a specified period. The reference is to calendar quarters. A year of work can, depending on the amount and timing of covered wages and self-employment income, yield up to four Quarters of Coverage. The minimum amounts necessary to accrue four Quarters of Coverage for a year of work are set so low that most individuals with taxed and reported work exceed them by a wide margin. (During 2012 a total of $\$ 4,520$ in covered earnings accrues a full four quarters.)

\section{(c) Covered Earnings and Benefit Amount}

By the time most people are eligible for Social Security benefits, whether due to their own retirement or disability or the retirement, death, or disability of a family member, the basic facts on which their eligibility and benefit amount calculations rest have been established for some time. That is because the benefit provisions look back across a working lifetime using the same definitions as were applied year by year during that period in the imposition of the Payroll Tax. Only ten years of covered work (forty Quarters of Coverage) during a career are enough to secure Insured Status for OldAge Insurance. On the other hand, Insured Status for Disability Insurance requires that there be recent covered work, which can exclude individuals who have ample past employment to support retirement or survivors benefits but have left the labor market for a period to care for children or adult family members or simply due to unemployment.

The arithmetic of Social Security benefit calculation begins with the insured worker's Primary Insurance Amount (PIA). Those entitled to benefits start out with a base monthly payment that is a defined percentage of that Primary Insurance Amount. In the case of Primary Benefits that percentage is 100\%. The PIA-based amount is, in some cases, adjusted depending on the age at which the person begins benefits. Further, if a beneficiary continues to receive earnings after applying for benefits prior to the individual's Full Retirement Age, earnings above a set annual amount will produce a reduction in benefits. 
The Primary Insurance Amount is based on the individual's Average Indexed Monthly Earnings. That figure is calculated from the worker's earnings in covered work over most of his or her career, indexed in relation to increases over time in national average wages so as to translate earlier earnings figures into recent earnings levels. The indexing year used is that which is two years prior to the worker's Year of Eligibility. (That is the year in which the worker could claim benefits or in the case of survivors benefits the year of the worker's death even if benefits are not begun until later.) Not all years enter into this Average Indexed Monthly Earnings figure. The Social Security Act contains a formula that identifies a number of low earnings years (at least five in the case of a worker who has lived to age 62) that can be dropped before calculating the average. In addition, a Disability Freeze will remove periods of disability from the calculation.

The Average Indexed Monthly Earnings figure is converted into the worker's Primary Insurance Amount by applying a series of multipliers. The Primary Insurance Amount equals 90\% of a first low band of Average Indexed Monthly Earnings plus $32 \%$ of a large middle band plus $15 \%$ of all earnings above that middle band. The boundaries between these bands, termed the Bend Points, are adjusted automatically to keep up with rising earnings. (For workers becoming eligible in 2012 the $90 \%$ band covers the first $\$ 767$ of Average Indexed Monthly Earnings; the 32\% band, from $\$ 768$ through $\$ 4,624$; the $15 \%$ band, over $\$ 4,642$.) This formula produces a Primary Insurance Amount that is more adequate for low income than high income workers. An alternative Special Minimum Primary Insurance Amount applies to workers with lengthy careers of low income work. Finally, under Social Security's Windfall Elimination Provision, workers receiving public pensions based on work that was not covered by Social Security have their Primary Insurance Amounts calculated under a different formula that yields lower monthly amounts.

In years after the initial Primary Insurance Amount calculation that amount and consequently all benefits based on it are subject to upward adjustment because of Social Security's Cost-of-Living Adjustment or COLA. The adjustment, which occurs when the cost-of-living increases, is driven by the Consumer Price Index prepared by the Department of Labor. In general, the benefit increase equals the percentage increase in the Consumer Price Index for Urban Wage Earners and Clerical Workers (CPI-W) measured from the third quarter of the previous year to the third quarter of the current year. If there is no increase in the CPI-W, there is no Cost-of-Living Adjustment.

A cap on the total monthly benefits payable on the account of a particular worker, the Family Maximum, has no effect on Primary Benefits but can lead to the pro rata reduction of Auxiliary Benefits received on that account. However, benefits paid to divorced former spouses and, under limited circumstances, even current legal spouses are paid outside that cap.

\section{Possible Changes That Have Been Part of Recent "Sustainability" Proposals}

Schemes that would trim Social Security costs by modifying the benefit formula invariably leave current recipients and those close to the age of eligibility for Old-Age Insurance alone. For younger workers, recent plans have proposed reducing the multiplier in the Primary Insurance Amount formula for the top band, in some cases 
with the addition of a fourth band. This focuses future benefit reduction on the highest earners. Some plans that aim to take account of future increases in longevity would adjust the PIA formula as life-spans increase. Private account proposals that seek their longterm substitution for Social Security invariably provide for a Social Security benefit reduction based on the amounts placed in the envisioned accounts.

Finally, reflecting the view that the current measure of cost of living increases overstates the true effect of inflation on beneficiaries, a number of plans propose replacing it with an alternate measure developed by the Bureau of Labor Statistics known as the "chainweighted" Consumer Price Index for All Urban Consumers. If enacted this would, in all likelihood, apply to current beneficiaries as well as future ones.

While the layers of Auxiliary Benefits bestowed on spouses, former spouses, surviving spouses and parents, and children account for over 14\% of Social Security's benefit payments and presume family patterns that no longer fit the lives of many workers, adjustments in that structure have received very little attention in recent proposals.

Some proposals that include forms of benefit reduction also incorporate benefit formula changes for particularly vulnerable populations entailing some increased cost. Examples include: a) increasing the Special Minimum Primary Insurance Amount so so as to provide benefits at the proverty level or more at least for steadily employed low-earnings workers and $b$ ) providing a benefit increment for those who have spent a very long period living on benefits ( 20 years after first eligibility, in the case of one proposal).

\section{(d) Age as Factor Bearing on Eligibility and Benefit Amount}

The eligibility requirements for Old-Age Insurance and Auxiliary Benefits for spouses, divorced former spouses, and suriviving spouses all include age thresholds. Surviving spouses (unless they are caring for eligible children) must be at least 60 years old. The others must be at least 62 . However, those who claim benefits at the earliest possible age suffer a reduction in benefit amount. The full amount is available only to individuals who do not claim benefits until attaining their Full Retirement Age. That benchmark age was 65 for beneficiaries born before 1938. Under current law it is increasing in steps for successive cohorts, but will plateau at 67 for those born in 1960 and thereafter. For each month of benefits received prior to Full Retirement Age the law specificies a percentage reduction (which varies among benefit types). In addition, continuing to work and receive earnings above a set annual amount prior to one's Full Retirement Age produces a reduction of benefits. Finally, those who continue to delay claiming Old-Age Insurance after reaching Full Retirement Age receive a Delayed Retirement Credit for each month of delay up to age 70. The Full Retirement Age is also the point at which recipients of Disability Insurance are switched over to Old-Age Insurance. (Since there is a strong correlation between advanced age and disability, some of the cost savings to Social Security achieved by moving back the program's Full Retirement Age are offset by increased claims for Disability Insurance benefits. 


\section{Possible Changes That Have Been Part of Recent "Sustainability" Proposals}

Pointing to continuing increases in longevity, some plans have proposed moving back the current eligibility theshold ages, even indexing them on an ongoing basis to changes in life expectancy. More common are proposals to continue the increase in Full Retirement Age for cohorts born after 1960 . 